\title{
Analysing the causes of chronic cough: relation to diesel exhaust, ozone, nitrogen oxides, sulphur oxides and other environmental factors

\author{
Beatrix Groneberg-Kloft ${ }^{1}$, Thomas Kraus ${ }^{2}$, Anke van Mark ${ }^{3}$, Ulrich Wagner ${ }^{4}$ \\ and Axel Fischer*1
}

\author{
Address: ${ }^{1}$ Division of Allergy Research, Charité - Universitätsmedizin Berlin, Free University and Humboldt-University, 13353 Berlin, Germany, \\ 2Institute of Occupational Medicine, University School of Medicine, RWTH Aachen, 52074 Aachen, Germany, ${ }^{3}$ Institute of Occupational \\ Medicine, University Lübeck, D-23538 Lübeck, Germany and ${ }^{4}$ Department of Medicine, Pulmonary and Critical Care Division, Philipps- \\ University, D-35043 Marburg, Germany \\ Email: Beatrix Groneberg-Kloft - beatrix.groneberg-kloft@charite.de; Thomas Kraus - thomas.kraus@post.rwth-aachen.de; Anke \\ van Mark - anke.wussow@uni-luebeck.de; Ulrich Wagner - wagnerul@aol.com; Axel Fischer* - axel.fischer@charite.de \\ * Corresponding author
}

Published: 18 May 2006

Journal of Occupational Medicine and Toxicology 2006, I:6 doi:10.1 I86/1745-6673-1-6

This article is available from: http://www.occup-med.com/content/I/I/6

(c) 2006 Groneberg-Kloft et al; licensee BioMed Central Ltd.

This is an Open Access article distributed under the terms of the Creative Commons Attribution License (http://creativecommons.org/licenses/by/2.0), which permits unrestricted use, distribution, and reproduction in any medium, provided the original work is properly cited.
Received: 05 August 2005

Accepted: 18 May 2006

\begin{abstract}
Air pollution remains a leading cause of many respiratory diseases including chronic cough. Although episodes of incidental, dramatic air pollution are relatively rare, current levels of exposure of pollutants in industrialized and developing countries such as total articles, diesel exhaust particles and common cigarette smoke may be responsible for the development of chronic cough both in children and adults. The present study analyses the effects of common environmental factors as potential causes of chronic cough. Different PubMed-based researches were performed that related the term cough to various environmental factors. There is some evidence that chronic inhalation of diesel can lead to the development of cough. For long-term exposure to nitrogen dioxide (NO2), children were found to exhibit increased incidences of chronic cough and decreased lung function parameters. Although a number of studies did not show that outdoor pollution directly causes the development of asthma, they have demonstrated that high levels pollutants and their interaction with sunlight produce ozone (O3) and that repeated exposure to it can lead to chronic cough. In summary, next to the well-known air pollutants which also include particulate matter and sulphur dioxide, a number of other indoor and outdoor pollutants have been demonstrated to cause chronic cough and therefore, environmental factors have to be taken into account as potential initiators of both adult and pediatric chronic cough.
\end{abstract}

\section{Introduction}

Coughing and mucus secretion are coordinated neuronal reflexes that protect the respiratory tract from noxious exogenous substances under physiological conditions. However, within chronic exposure to noxious substances such as tobacco smoke, urban dust, or occupational fac- tors [1-3], the originally protective mechanisms may lead to a states of chronic distress with hypersecretion and chronic coughing [4-10]. The neurophysiology of the cough reflex and its relation to bronchoconstriction and different forms of adult and pediatric asthma is very complex [11]. However, there is little doubt that chronic 
cough can be related to the exposure to different environmental air pollutants. Amongst them, pollutants such as diesel exhaust, ozone, nitrogen and sulphur dioxide have all been suggested to participate as main causes or co-factors in the development of chronic cough [12].

These suggestions do not only base on epidemiological and clinical observations, but also on the neurophysiological and -anatomical understanding of the cough reflex. In this respect it is generally accepted, that airway pollutantcaused airway irritation leading to chronic cough displays a complex phenomenon involving a variety of reflex mechanisms [13-19].

Neurophysiologically, a subgroup of rapidly adapting receptors (RARs) among the three major types of vagal sensory receptors is suggested to act as "cough receptors". Next to these RARs, a further effect by bronchopulmonary $\mathrm{C}$-fibers on the cough reflex has been suggested, and there are data indicating that i.e. ozone, one of the main environmental air pollutants, exerts an influence on vagal-sensory innervation [20-24]. Also, transient receptor potential vanilloid-1 seems to play a role in the mediation of the cough reflext $[25,26]$ and airway nerves and their mediators in general are likely to play an important role in the general pathology of cough and airway inflammation [27-33].

In the light of the clinical, epidemiological and experimental data which point to a major role of environmental pollutants as co-factors for the development and progression of chronic cough, the present study analysed the data available on the association between environmental pollutants and chronic cough on the basis of a large amount of existing recent literature reviews and original articles $[12,13,34-55]$. Figure 1 illustrates the deposition of some environmental pollutants related to cough in the respiratory tract.

\section{Material and methods Methods}

A PubMed research was performed using terms such as "cough", "environmental", and various environmental factors and publication types (date: 2006-03-03). Articles were screened for their contents and relevant data was analysed.

\section{Results and discussion Frequency of research related to cough and environmental factors}

For the terms "cough" and journal article as publication type 23248 entries were registrated in the PubMed while 2463 review articles containing the term cough were found (Fig. 2). To analyse specific articles related to environmental medicine, the search was narrowed and differ- ent terms related to environmental factors were encluded (Fig. 3). To analyse the frequency of scientific studies related to environmental factors and cough, different publication dates were analysed in in general, an increasing frequency was found beginning i.e. in the year 1980 with 6 articles and increasing from 1995 with 28 articles to a number of 65 articles in the year 2004 (Fig. 4).

\section{Diesel exhaust}

The term "diesel" was only found in a low frequency in studies related to cough (Fig. 3). Next to health effects caused by exposure to tobacco smoke, there has been an increasing attention to the effects of diesel emissions in the past years [12]. Both on the epidemiological and the experimental field, a variety of studies demonstrated a relation between diesel exhaust and respiratory diseases such as chronic cough, asthma, chronic bronchitis or cancer. Diesel exhausts consists of a variety of components: Next to products arising from the incomplete combustion (carbon monoxide, nitrogen oxides, hydrocarbons including partially oxidized forms such as ketones, aldehydes, phenols, and sulphur compounds), diesel exhaust contains substances deriving from the complete air and carbon combustion such as nitrogen, carbon dioxide and water. In comparison to gasoline engine exhausts, diesel emissions contain a far greater amount of nitrogen oxides and aldehydes but less carbon monoxide. Next to these components, diesel exhaust also includes submicron particles and fine particles below $10 \mu \mathrm{m}$ which can cause a variety of respiratory effects.

Chronic effects of exposure to diesel emission have been assessed by several studies and the prevalence of chronic cough varied from 29 to $37 \%$ among smokers and between 8 to $16 \%$ in nonsmokers. The risk ratio (observed/expected) for diesel emission exposed individuals varied between 1.2 and 2.3 and there was a consistent finding for an increased risk of chronic cough among the studies [56-59]. In general, the non-malignant respiratory effects of diesel exhaust exposure can be summarized as an increased prevalence of chronic cough and also of phlegm production and of dyspnea. Also, the $\mathrm{FEV}_{1}$ of diesel exposed individuals can show a significant decrease. However, the diesel emissions can not be incriminated as indirect or direct causes due to confounding by other exposures such as tobacco smoke and for the most part of the data, no exposure-response relationships are present.

\section{Nitrogen dioxide}

Nitrogen dioxide (NO2) is an oxidizing free radical which can initiate a number of destructive pathways in the human body $[12,60]$. NO2 plays an important role in atmospheric pollution and might be a major cause of human respiratory problems such as chronic cough in 


\section{Pollutant Solubility Site of effect}

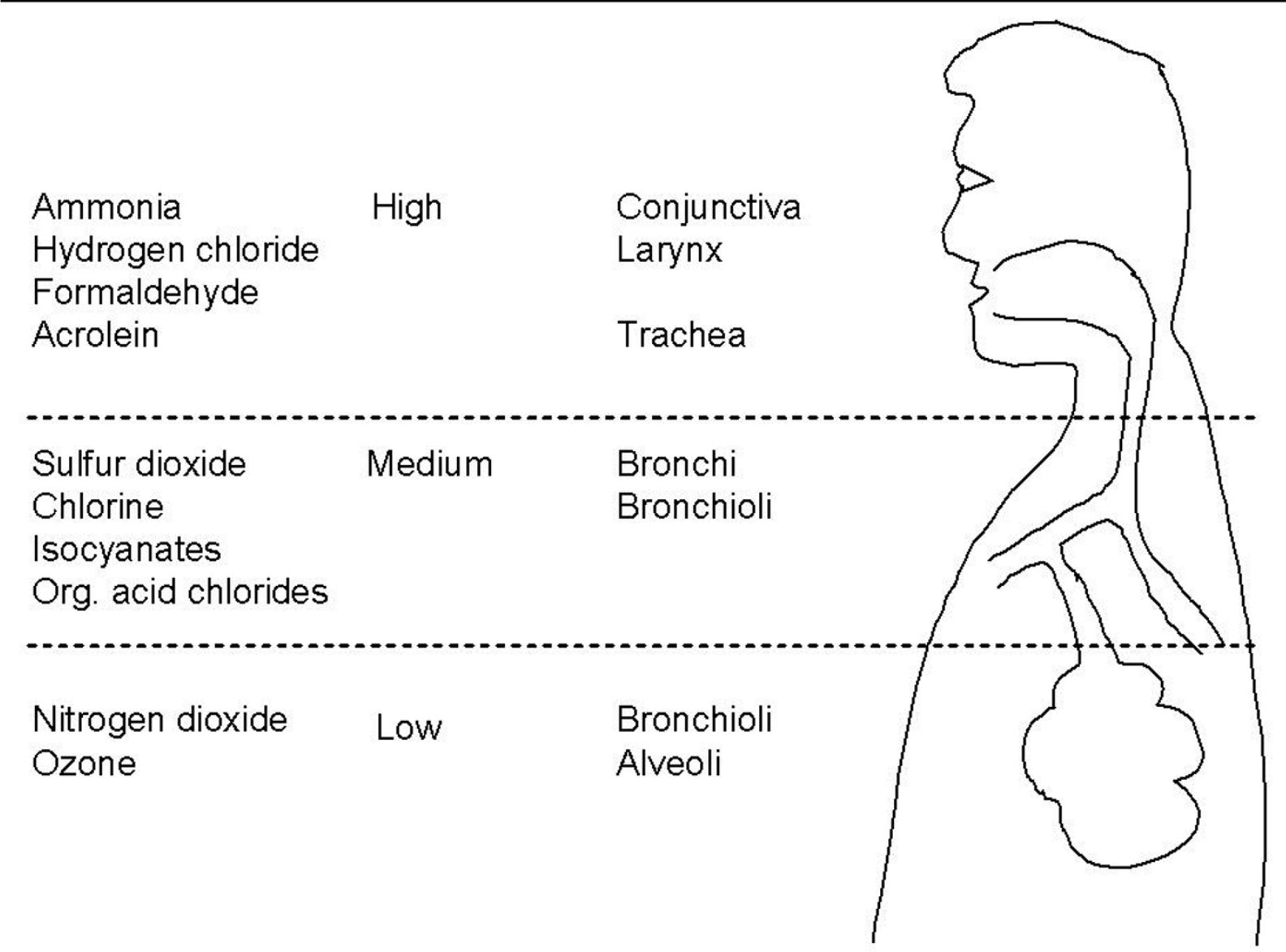

Figure I

Deposition of environmental polluatants in the respiratory tract. (modified from [l I ]).

urban areas [61]. Numerous studies have addressed a relationship between NO2 and chronic cough (Fig. 3).

In 1985, primary schoolchildren and their mothers were surveyed in Hong Kong to study the possible relationship of nitrogen dioxide (NO2)-related environmental air pollution to respiratory illnesses [62]. Using personal samplers to measure $\mathrm{NO} 2$, the study also assessed the major sources of $\mathrm{NO} 2$ in the indoor environment and examined if an increased $\mathrm{NO} 2$ concentration is positively associated with respiratory symptoms. The levels of NO2 among the examined 319 mothers were increased by $21 \%$ if there was dust exposure found at the mothers' workplace. There was an increase of $18 \%$ if they used cooking fuels such as kerosene or liquid petroleum, and an increase of $11 \%$ when the kitchens did not have a ventilation system. For chronic cough, an increase in NO2 levels of $18 \%$ was found among those with chronic cough. The levels of NO2 among the examined 362 children were correlated with NO2 levels measured in their classrooms, all of which had opened windows so that the NO2 came from outdoors [62].

The effect of indoor nitrogen dioxide exposure on the incidence of respiratory symptoms and pulmonary function level was also examined in an American cohort of 1,567 Caucasian children aged between seven and eleven years and examined from 1983 through 1988 [63]. Nitrogen dioxide was assessed three indoor locations over 2 consecutive weeks in the winter and summer periods and household annual averages of the nitrogen dioxide concentrations were assessed as continuous variables and as four categories. Multiple logistic regression analysis of symptom reports after indoor monitoring then revealed that an increased cumulative incidence of lower respiratory symptoms was positively associated with a 15-ppb 


\section{PubMed Search}

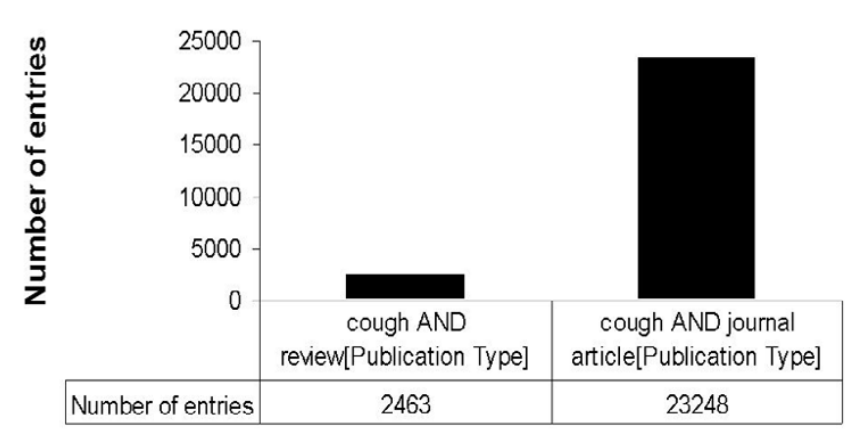

Figure 2

PubMed search for the terms "cough" and publication types.

increase in the household annual nitrogen dioxide mean (odds ratio $(\mathrm{OR})=1.4,95 \%$ confidence interval $(95 \% \mathrm{Cl})$ 1.1 to 1.7$)$. The response variable indicated the report of one or more of the following symptoms: chronic cough, chronic phlegm, attacks of shortness of breath with wheeze, chronic wheeze, or bronchitis. School girls showed a stronger association than boys (OR $=1.7,95 \%$ Cl 1.3-2.2 vs. $\mathrm{OR}=1.2,95 \% \mathrm{Cl} 0.9-1.5)$. An analysis of pulmonary function measurements showed no consistent effect of nitrogen dioxide. These results were consistent with earlier reports based on categorical indicators of household nitrogen dioxide sources and provided a specific association of respiratory diseases such as chronic cough with nitrogen dioxide as measured in children's homes [63].

Also, the SAPALDIA study examined the association between NO2 and chronic cough and it was reported that an increase of $10 \mu \mathrm{g} / \mathrm{m}^{3}$ in pollutant levels was associated with an increase in the prevalence of chronic cough [64]. Next to this study, the Swiss Study on Childhood Allergy and Respiratory Symptoms with Respect to Air Pollution, Climate and Pollen (SCARPOL-study) [65] also reported that the symptom rate of chronic cough, adjusted for individual risk factors, was positively associated with $\mathrm{NO} 2$ [65].

Together, these data indicate that long-term NO2 exposure leads to increased incidences of chronic cough and decreased lung function. Also, weak associations between short-term NO2 exposure and respiratory symptoms and a decrement in lung function parameters were found in children, but not consistently in exposed women.

\section{PubMed Search}

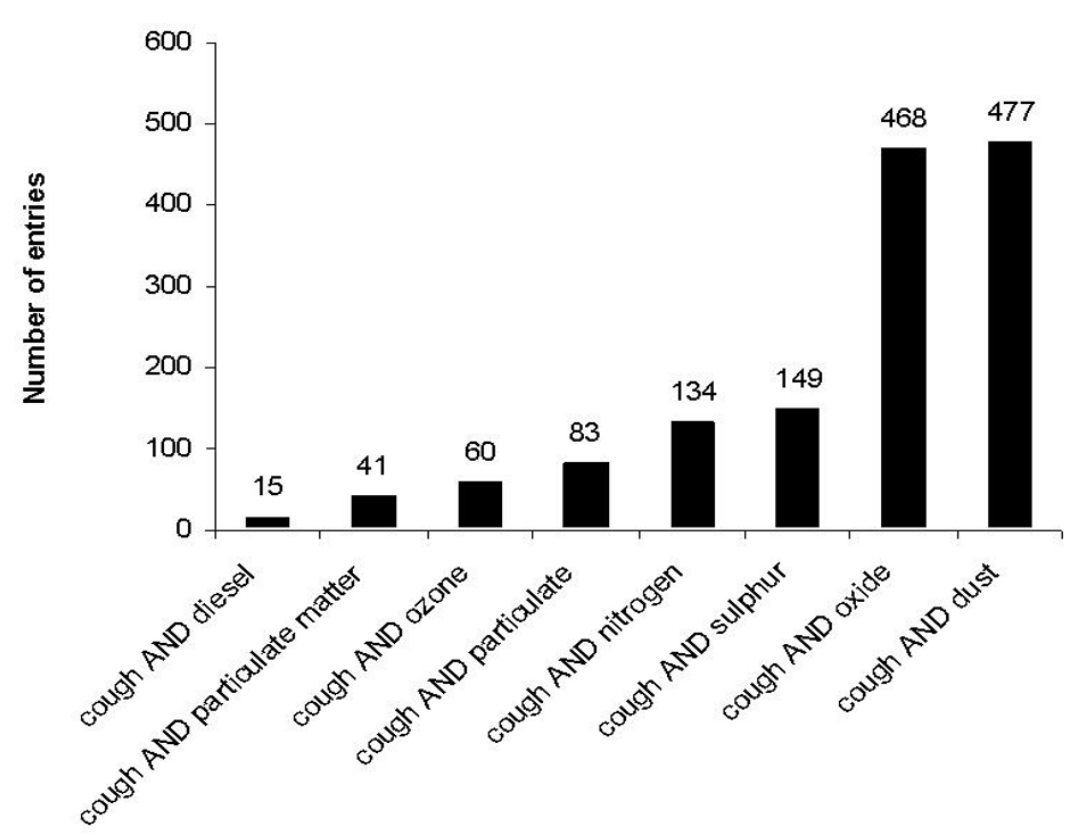

Figure 3

PubMed search for the terms "cough" and different environmental factors. 
cough AND environmental AND [Publication Year]

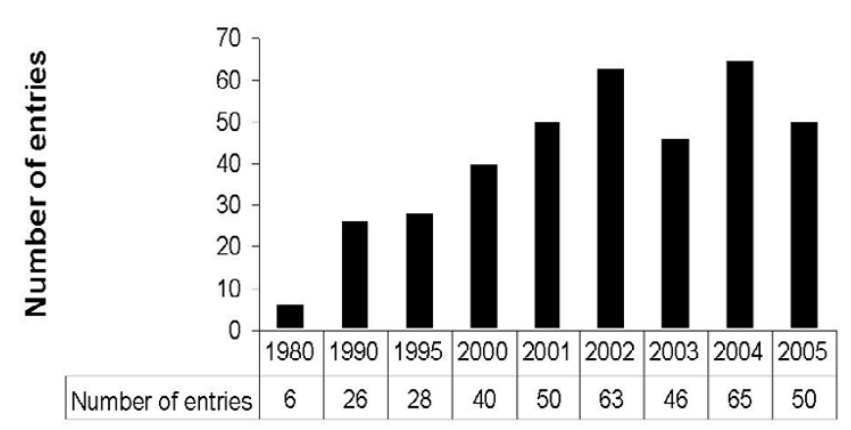

\section{Figure 4}

Frequency of studies related to cough and environmental factors as assessed by a PubMed search for the terms "cough" and "environmental" and different publication dates.

\section{Sulphur dioxide}

With regard to one of the most dramatical urban environmental exposures to air pollutants, the London smogs [66-70], sulphur dioxide (SO2) is known as major respiratory irritant since many years. Next to its acute effects, SO2 may also be related to the incidence of chronic cough [12]. In total, 149 PubMed entries inclided the terms "cough" and "sulphur" (Fig. 3). Some of them, but others not, found associations between $\mathrm{SO} 2$ exposure and respiratory symptoms such as chronic cough and daily mortality and morbidity. In general, single-pollutant correlations sometimes disappeared when other pollutants such as suspended particulate matter (SPM) were included.

A study on indoor air pollution and respiratory health in urban and rural China revealed interesting relations between chronic cough and SO2 [71]: During the summer of 1999 , data on the respiratory health outcomes and relevant covariates was collected from 3,709 Chinese adult individuals in the cities of Beijing, Anqing City, and in rural communities. Indoor SO2 was measured in a random sample of selected households and using logistic regression and controlling for important covariates (excluding PM10 and SO2) and familial intraclass correlation, highly significant differences were found between study areas in the prevalence of chronic cough. In general, the lowest prevalence of respiratory symptoms was observed in Anqing City, a higher prevalence in rural Anqing, and the highest prevalence in Beijing. However, median indoor concentrations of SO2 were similar in all three areas (Beijing: $14 \mathrm{microg} / \mathrm{m} 3$, Anqing City: 25 microg/m3, rural Anqing: 20 microg/m3) [71].
A further study in Canada also addressed the association of inhalable sulfates, SO2 and childhood chronic cough [72]: Preadolescent school children, aged 7-11 years, who resided in 10 rural Canadian communities areas of moderate and low exposure to regional sulfate and ozone pollution were examined. The communities were situated in central Saskatchewan, a low-exposure region, and in southwestern Ontario, an area with moderately increased SO2 exposures resulting from a long-distance atmospheric transport of polluted air masses. In this cross-sectional study, the annual mean and 90th percentile concentrations of inhalable sulfates were three times higher in Ontario than in Saskatchewan but levels of SO2 were low in both regions. After controlling for the effects of age, sex, parental smoking, parental education, and gas cooking, no significant regional differences were observed in rates of chronic cough [72]. In the SAPALDIA study, there were no data on the association between SO2 and chronic cough reported [64]. However, other European studies found an association between $\mathrm{SO} 2$ exposure and chronic cough [73].

\section{Ozone}

Ozone is a very powerful oxidant and also a very toxic air pollutant $[12,74]$. As a gaseous air pollutant, its primary target organ is the respiratory tract [75] and exposure to even slightly elevated concentrations of ozone leads to a range of respiratory symptoms including chronic cough [76-78].

A variety of studies focused on the relation between ozone-exposure and chronic cough (Fig. 3) and revealed controversial results. For instance, the effects of ambient ozone (O3) on respiratory function and acute respiratory symptoms were assessed 7- to 9-yr-old schoolchildren followed longitudinally at 1 - to 2 -wk intervals over a period of 6 months at three schools in Mexico City. The maximum $\mathrm{O} 3$ level which was measured exceeded the World Health Organization guideline of $80 \mathrm{ppb}$ and the U.S. standard of $120 \mathrm{ppb}$ in every week. For an increase from lowest to highest in the mean $\mathrm{O} 3$ level during the $48 \mathrm{hr}$ before spirometry (53 ppb), logistic regression estimated relative odds of 1.7 for a child reporting cough on the day of spirometry [79].

In the cross-sectional study in Canada with preadolescent school children, aged 7-11 years, in the low-exposure region central Saskatchewan, and in the moderately polluted area in southwestern Ontario, no significant regional differences were observed in rates of chronic cough. Here, the annual mean of the 1-hr daily maxima of ozone was higher in Ontario (46.3 ppb) than in Saskatchewan (34.1 ppb), with 90th percentile concentrations of $80 \mathrm{ppb}$ in Ontario and $47 \mathrm{ppb}$ in Saskatchewan and sum- 
mertime 1-hr daily maxima means were $69.0 \mathrm{ppb}$ in Ontario and $36.1 \mathrm{ppb}$ in Saskatchewan [72].

In the Swiss SAPALDIA and SCARPOL studies, no associations between ozone and chronic cough were found $[64,65]$.

In contrast to these epidemiological data, there is a large body of experimental evidence that ozone influences pulmonary vagal-sensory nerve fibers which are suggested to be major mediators of the cough reflex $[24,80]$. However, these effects may be reflected by the known short-term acute effects of ozone such as pulmonary function decrements, increased airway responsiveness and airway inflammation.

In this respect, exposure-response relations are non-linear for the respective associations between $\mathrm{O} 3$ and FEV1, inflammatory changes, and changes in hospital admissions, whereas it has been reported that the relation between percent change in symptom exacerbation among adults and asthmatics is linear. Also, the single-pollutant associations between ozone exposure and hospital admissions for respiratory diseases and daily mortality were shown to be statistically significant, even in multi-pollutant models.

\section{Other environmental causes}

There is also a variety of other environmental factors which have been reported to contribute to the prevalence of chronic cough. In this respect, recent reports have demonstrated a relation between allergen such as Humicola fuscoatra in indoor air and chronic cough (combined with sputum eosinophilia) [81] or arsenic contaminated well water in Bangladesh [82]. Here, a prevalence comparison study of chronic cough and chronic bronchitis among subjects with or without arsenic exposure revealed a crude prevalence ratio for chronic cough and chronic bronchitis amounted to 2.1 (95\% CI 0.7-6.1). The prevalence ratios for chronic cough increased with increasing exposure, i.e., 1.0, 1.6, 2.7 and 2.6 for the exposure categories using unexposed as the reference, indicating that long-term ingestion of arsenic exposure can cause chronic cough [82].

Also, depleted uranium, which is a radioactive heavy metal that is commonly used in missiles, has been shown to be associated with chronic cough as a health risk [83].

Next to microbially-related chronic cough [84], a further environmental cause may be found in exposure to Formaldehyde: [85]. A study on the relation of chronic respiratory symptoms and pulmonary function to indoor formaldehyde (HCHO) examined in a sample of 298 chil- dren (6-15 years of age) and 613 adults revealed an association to chronic cough.

\section{Conclusion}

Environmental air pollution is not only one of the causes that might lead to severe diseases such as cancer or cardiorespiratory disease, but also associated with the prevalence of chronic cough both in adults and children.

Although episodes of incidental, dramatic air pollution are relatively rare, the currently found levels of exposure to pollutants especially in developing countries may increase the prevalence of chronic cough. Next to well-known air pollutants such as nitrogen dioxide, a number of other indoor and outdoor pollutants have recently been demonstrated to cause chronic cough and therefore, environmental factors have to be taken into account as potential initiators of both adult and pediatric chronic cough.

\section{Declaration of competing interests}

The author(s) declare that they have no competing interests.

\section{Authors' contributions}

BGK and AF have planed the study. BGK has peformed the data analysis and interpretation and drafted the article. TK, AVM and UW have all been involved in interpreting and discussing the data and revising the article critically for important intellectual content.

\section{References}

I. Yelin E, Katz P, Balmes J, Trupin L, Earnest G, Eisner M, Blanc P: Work Life of Persons with Asthma, Rhinitis, and COPD: A Study Using a National, Population-Based Sample. J Occup Med Toxicol 2005, I:2.

2. Groneberg DA, Fischer A: Occupational Medicine and Toxicology. J Occup Med Toxicol 2005, I:I.

3. Groneberg DA, Nowak D, Wussow A, Fischer A: Chronic cough due to occupational factors. J Occup Med Toxicol 2005, I:3.

4. Groneberg DA, Wagner U, Chung KF: Mucus and fatal asthma. Am J Med 2004, I | 6:66-67.

5. Chung KF, Groneberg DA: Effects of cigarette smoke on pulmonary homeostasis. Am J Respir Cell Mol Biol 2005, 32:167.

6. Chung KF, Caramori G, Groneberg DA: Airway obstruction in chronic obstructive pulmonary disease. N Engl J Med 2004, 35I:1459-I46I.

7. Groneberg DA, Eynott PR, Lim S, Oates T, Wu R, Carlstedt I, Roberts P, McCann B, Nicholson AG, Harrison BD, Chung KF: Expression of respiratory mucins in fatal status asthmaticus and mild asthma. Histopathology 2002, 40:367-373.

8. Groneberg DA, Eynott PR, Oates T, Lim S, Wu R, Carlstedt I, Nicholson AG, Chung KF: Expression of MUC5AC and MUC5B mucins in normal and cystic fibrosis lung. Respir Med 2002, 96:8I-86.

9. Springer J, Groneberg DA, Pregla R, Fischer A: Inflammatory cells as source of tachykinin-induced mucus secretion in chronic bronchitis. Regul Pept 2005, I 24:195-201.

10. Groneberg DA, Peiser C, Dinh QT, Matthias J, Eynott PR, Heppt W, Carlstedt I, Witt C, Fischer A, Chung KF: Distribution of respiratory mucin proteins in human nasal mucosa. Laryngoscope 2003, I I 3:520-524.

II. Nowak D: Chemosensory irritation and the lung. Int Arch Occup Environ Health 2002, 75:326-331.

12. Balmes J, Becklake M, Blanc P, Henneberger P, Kreiss K, Mapp C, Milton D, Schwartz D, Toren K, Viegi G: American Thoracic Society 
Statement: Occupational contribution to the burden of airway disease. Am J Respir Crit Care Med 2003, 167:787-797.

13. Chung KF, Widdicombe J: Acute and chronic cough. Pulm Pharmacol Ther 2004, 17:47I-473.

14. Carr MJ: Plasticity of vagal afferent fibres mediating cough. Pulm Pharmacol Ther 2004, i 7:447-45I.

15. Mazzone SB: Sensory regulation of the cough reflex. Pulm Pharmacol Ther 2004, 17:361-368.

16. Canning BJ, Mazzone SB, Meeker SN, Mori N, Reynolds SM, Undem $B$ J: Identification of the tracheal and laryngeal afferent neurones mediating cough in anaesthetized guinea-pigs. J Physio 2004, 557:543-558.

17. Belvisi MG: Airway sensory innervation as a target for novel therapies: an outdated concept? Curr Opin Pharmacol 2003, 3:239-243

18. Widdicombe JG: Overview of neural pathways in allergy and asthma. Pulm Pharmacol Ther 2003, 16:23-30.

19. Belvisi MG: Sensory nerves and airway inflammation: role of $\mathbf{A}$ delta and C-fibres. Pulm Pharmacol Ther 2003, 16:1-7.

20. Adcock J], Douglas G], Garabette M, Gascoigne M, Beatch G, Walker $M$, Page CP: RSD93 I, a novel anti-tussive agent acting on airway sensory nerves. BrJ Pharmacol 2003, 138:407-416.

21. Undem BJ, Carr MJ, Kollarik M: Physiology and plasticity of putative cough fibres in the Guinea pig. Pulm Pharmacol Ther 2002, 15:193-198.

22. Canning BJ: Interactions between vagal afferent nerve subtypes mediating cough. Pulm Pharmacol Ther 2002, I5:187-192.

23. Eccles R, Lee PC: Cough induced by airway vibration as a model of airway hyperreactivity in patients with acute upper respiratory tract infection. Pulm Pharmacol Ther 2004, 17:337-342

24. Lee LY, Kwong K, Lin YS, Gu Q: Hypersensitivity of bronchopulmonary C-fibers induced by airway mucosal inflammation: cellular mechanisms. Pulm Pharmacol Ther 2002, 15:199-204.

25. Trevisani M, Gazzieri D, Benvenuti F, Campi B, Dinh QT, Groneberg DA, Rigoni M, Emonds-Alt X, Creminon C, Fischer A, Geppetti P, Harrison S: Ethanol Causes Inflammation in the Airways by a Neurogenic and TRPVI-Dependent Mechanism. J Pharmacol Exp Ther 2004.

26. Groneberg DA, Niimi A, Dinh QT, Cosio B, Hew M, Fischer A, Chung $\mathrm{KF}$ : Increased expression of transient receptor potential vanilloid-I in airway nerves of chronic cough. Am J Respir Crit Care Med 2004, 170:1276-1280.

27. Groneberg DA, Chung KF: Models of chronic obstructive pulmonary disease. Respir Res 2004, 5: 18 .

28. Thai Dinh Q, Groneberg DA, Peiser C, Joachim RA, Frossard N, Arck PC, Klapp BF, Fischer A: Expression of substance $\mathbf{P}$ and nitric oxide synthase in vagal sensory neurons innervating the mouse airways. Regul Pept 2005, I 26: I89-194.

29. Groneberg DA, Heppt W, Cryer A, Wussow A, Peiser C, Zweng M, Dinh QT, Witt C, Fischer A: Toxic rhinitis-induced changes of human nasal mucosa innervation. Toxicol Pathol 2003, 3I:326-331.

30. Groneberg DA, Heppt W, Welker P, Peiser C, Dinh QT, Cryer A Zweng M, Witt C, Fischer A: Aspirin-sensitive rhinitis associated changes in upper airway innervation. Eur Respir J 2003 22:986-991

31. Groneberg DA, Quarcoo D, Frossard N, Fischer A: Neurogenic mechanisms in bronchial inflammatory diseases. Allergy 2004 59:1139-1152.

32. Heppt W, Peiser C, Cryer A, Dinh QT, Zweng M, Witt C, Fischer A Groneberg DA: Innervation of human nasal mucosa in environmentally triggered hyperreflectoric rhinitis. J Occup Environ Med 2002, 44:924-929.

33. Heppt W, Thai Dinh Q, Cryer A, Zweng M, Noga O, Peiser C, Melvan $M$, Witt $C$, Fischer A, Groneberg DA: Phenotypic alteration of neuropeptide-containing nerve fibres in seasonal intermittent allergic rhinitis. Clin Exp Allergy 2004, 34: I I05-I I I0.

34. Belvisi MG, Geppetti P: Cough. 7: Current and future drugs for the treatment of chronic cough. Thorax 2004, 59:438-440.

35. de Jongste JC, Shields MD: Cough . 2: Chronic cough in children. Thorax 2003, 58:998-1003.

36. Dicpinigaitis PV: Cough. 4: Cough in asthma and eosinophilic bronchitis. Thorax 2004, 59:7I-72.

37. Fontana GA, Pistolesi M: Cough. 3: chronic cough and gastrooesophageal reflux. Thorax 2003, 58:1092-1095.
38. McGarvey LP: Cough . 6: Which investigations are most useful in the diagnosis of chronic cough? Thorax 2004, 59:342-346.

39. Morice AH, Kastelik JA: Cough. I: Chronic cough in adults. Tho$\operatorname{rax} 2003,58: 901-907$.

40. Morice AH, Geppetti P: Cough. 5: The type I vanilloid receptor: a sensory receptor for cough. Thorax 2004, 59:257-258.

4I. Ahmedzai SH: Cough in cancer patients. Pulm Pharmacol Ther 2004, 17:415-423.

42. Chung KF, Widdicombe JG: Cough as a symptom. Pulm Pharmacol Ther 2004, 17:329-332.

43. Chung KF, Chang $A B$ : Therapy for cough: active agents. Pulm Pharmacol Ther 2002, 15:335-338.

44. Dicpinigaitis PV: Potential new cough therapies. Pulm Pharmacol Ther 2004, 17:459-462.

45. Fong J, Sandhu G, Ellaway P, Davey N, Strutton P, Murphy K, Guz A What do we know about how humans cough? Pulm Pharmacol Ther 2004, 17:43I-434.

46. Fontana GA, Lavorini F, Geri P, Zanasi A, Piumelli R: Cough in children with congenital central hypoventilation syndrome. Pulm Pharmacol Ther 2004, 1 7:425-429.

47. Harrison NK: Idiopathic pulmonary fibrosis: a nervous cough? Pulm Pharmacol Ther 2004, 17:347-350.

48. Ing A): Cough and gastro-oesophageal reflux disease. Pulm Pharmacol Ther 2004, 17:403-4I3.

49. McGarvey LP, Ing AJ: Idiopathic cough, prevalence and underlying mechanisms. Pulm Pharmacol Ther 2004, 17:435-439.

50. Morice $\mathrm{AH}$ : Post-nasal drip syndrome--a symptom to be sniffed at? Pulm Pharmacol Ther 2004, 1 7:343-345.

51. Niimi A, Chung KF: Airway inflammation and remodelling changes in patients with chronic cough: do they tell us about the cause of cough? Pulm Pharmacol Ther 2004, 17:44I-446.

52. Page C, Reynolds SM, Mackenzie AJ, Geppetti P: Mechanisms of acute cough. Pulm Pharmacol Ther 2004, 17:389-391.

53. Pavord ID: Cough and asthma. Pulm Pharmacol Ther 2004 I7:399-402

54. Smith JA, Calverley PM: Cough in chronic obstructive pulmonary disease. Pulm Pharmacol Ther 2004, 17:393-398.

55. Morgan WK, Reger RB, Tucker DM: Health effects of diesel emissions. Ann Occup Hyg 1997, 41:643-658.

56. Gamble J, Jones W, Hudak J: An epidemiological study of salt miners in diesel and nondiesel mines. Am J Ind Med 1983, 4:435-458.

57. Gamble JF, Jones WG: Respiratory effects of diesel exhaust in salt miners. Am Rev Respir Dis 1983, 128:389-394.

58. Attfield MD, Trabant GD, Wheeler RW: Exposure to diesel fumes and dust at six potash mines. Ann Occup Hyg 1982, 26:8I7-83I.

59. Kirsch M, Korth HG, Sustmann R, de Groot H: The pathobiochemistry of nitrogen dioxide. Biol Chem 2002, 383:389-399.

60. Sauerbeck G, Parkin CS, Houston S, Whall C, Newton A, Carlyle J: Nitrogen dioxide and particle pollution near trunk roads and in towns of the south Midlands in England. J R Soc Health 2000, 120:183-187.

6I. Koo LC, Ho JH, Ho CY, Matsuki H, Shimizu H, Mori T, Tominaga S: Personal exposure to nitrogen dioxide and its association with respiratory illness in Hong Kong. Am Rev Respir Dis 1990, |41:11119-1126.

62. Neas LM, Dockery DW, Ware JH, Spengler JD, Speizer FE, Ferris BGJ: Association of indoor nitrogen dioxide with respiratory symptoms and pulmonary function in children. Am J Epidemiol 1991, 134:204-219.

63. Zemp E, Elsasser S, Schindler $C$, Kunzli N, Perruchoud AP, Domenighetti G, Medici T, Ackermann-Liebrich U, Leuenberger $P$, Monn C, Bolognini G, Bongard JP, Brandli O, Karrer W, Keller R, Schoni MH, Tschopp JM, Villiger B, Zellweger JP: Long-term ambient air pollution and respiratory symptoms in adults (SAPALDIA study). The SAPALDIA Team. Am J Respir Crit Care Med 1999, 159:1257-1266

64. Braun-Fahrlander C, Vuille JC, Sennhauser FH, Neu U, Kunzle T, Grize L, Gassner M, Minder C, Schindler C, Varonier HS, Wuthrich $B$ : Respiratory health and long-term exposure to air pollutants in Swiss schoolchildren. SCARPOL Team. Swiss Study on Childhood Allergy and Respiratory Symptoms with Respect to Air Pollution, Climate and Pollen. Am / Respir Crit Care Med 1997, 155:1042-1049.

65. Stone R: Air pollution. Counting the cost of London's killer smog. Science 2002, 298:2106-2107. 
66. Bell ML, Davis DL: Reassessment of the lethal London fog of 1952: novel indicators of acute and chronic consequences of acute exposure to air pollution. Environ Health Perspect 200I, I 09 Suppl 3:389-394.

67. Masood E: Once upon a smoggy day in London town. Nature 1996, 381:18I.

68. Thurston GD, Ito K, Lippmann M, Hayes C: Reexamination of London, England, mortality in relation to exposure to acidic aerosols during 1963-1972 winters. Environ Health Perspect 1989, 79:73-82.

69. Ito K, Thurston GD: Characterization and reconstruction of historical London, England, acidic aerosol concentrations. Environ Health Perspect 1989, 79:35-42.

70. Venners SA, Wang B, Ni J, Jin Y, Yang J, Fang Z, Xu X: Indoor air pollution and respiratory health in urban and rural China. Int J Occup Environ Health 2001, 7:173-18I.

7I. Stern BR, Raizenne ME, Burnett RT, Jones L, Kearney J, Franklin CA: Air pollution and childhood respiratory health: exposure to sulfate and ozone in 10 Canadian rural communities. Environ Res 1994, 66:125-142

72. Forsberg B, Stjernberg N, Wall S: Prevalence of respiratory and hyperreactivity symptoms in relation to levels of criteria air pollutants in Sweden. Eur J Public Health 1997, 7/3:291-296.

73. Bhalla DK: Ozone-induced lung inflammation and mucosal barrier disruption: toxicology, mechanisms, and implications. J Toxicol Environ Health B Crit Rev 1999, 2:31-86.

74. Mudway IS, Kelly FJ: Ozone and the lung: a sensitive issue. Mol Aspects Med 2000, $21: 1-48$.

75. Brunekreef B, Holgate ST: Air pollution and health. Lancet 2002, 360: $1233-1242$

76. Mathieu-Nolf M: Poisons in the air: a cause of chronic disease in children. J Toxicol Clin Toxicol 2002, 40:483-49I.

77. Oberdorster G: Pulmonary effects of inhaled ultrafine particles. Int Arch Occup Environ Health 200I, 74:I-8.

78. Castillejos M, Gold DR, Dockery D, Tosteson T, Baum T, Speizer FE: Effects of ambient ozone on respiratory function and symptoms in Mexico City schoolchildren. Am Rev Respir Dis 1992, I 45:276-282.

79. Irwin RS, Madison JM, Fraire AE: The cough reflex and its relation to gastroesophageal reflux. Am J Med 2000, 108 Suppl 4a:73S-78S.

80. Ogawa H, Fujimura M, Tofuku Y: Isolated chronic cough with sputum eosinophilia caused by Humicola fuscoatra antigen: the importance of environmental survey for fungus as an etiologic agent. J Asthma 2002, 39:33 I-336.

81. Milton AH, Rahman M: Respiratory effects and arsenic contaminated well water in Bangladesh. Int J Environ Health Res 2002, 12:175-179.

82. Abu-Qare AW, Abou-Donia MB: Depleted uranium--the growing concern. J Appl Toxicol 2002, 22: | 149-152.

83. Baboolal S, Rawlins SC: Seroprevalence of toxocariasis in schoolchildren in Trinidad. Trans R Soc Trop Med Hyg 2002, 96:139-143.

84. Krzyzanowski M, Quackenboss JJ, Lebowitz MD: Chronic respiratory effects of indoor formaldehyde exposure. Environ Res 1990, 52:117-125.

\section{Publish with Bio Med Central and every scientist can read your work free of charge}

"BioMed Central will be the most significant development for disseminating the results of biomedical research in our lifetime. "

Sir Paul Nurse, Cancer Research UK

Your research papers will be:

- available free of charge to the entire biomedical community

- peer reviewed and published immediately upon acceptance

- cited in PubMed and archived on PubMed Central

- yours - you keep the copyright
BioMedcentral 